\title{
POIÉTICAS NÃO EUROPEIAS EM TRADUÇÃO - REFUNDAÇÕES E REESCRITAS DESDE BRASIS
}

\author{
Álvaro Faleiros ${ }^{1}$ \\ 1-Universidade de São Paulo, São Paulo, São Paulo Brasil
}

É um esforço delicado propor um espectro tão amplo de possibilidades como o deste número especial, pois, falar em algo que não seja europeu é operar com assimétricas distinções. Primeiramente, em termos de população, a parte do mundo que compreende a Europa é consideravelmente menor do que esta que nosso número especial tenta humildemente não abarcar, mas, ao menos, vislumbrar. A Europa inteira cabe numa Amazônia, numa Rússia ou numa China. Em termos de população, a comparação segue desproporcionalmente assimétrica: como comparar as poucas centenas de milhões de europeus com os bilhões que fora da Europa proliferam? Entretanto, por seu poder colonial, mesmo se em franca decadência, a Europa e seu primo rico os Estados Unidos ainda se impõem com força (inclusive militar) como baliza civilizatória. Basta pensar na quantidade de intelectuais, artistas e outros refugiados que se deslocam dos quatro cantos do mundo rumo ao que Peeter Sloterdjik chama "Palácio de Cristal"; basta lembrar dos milhares de soldados estadunidenses e europeus em "missões de paz" pelo mundo. E não por acaso os escritos que aqui publicamos, inclusive este ensaio de abertura, é feito numa língua europeia. Língua esta, cuja literatura, para um dos grandes intelectuais da modernidade brasileira que é Antonio Candido, não passa de "frágil galho secundário da literatura portuguesa", ela mesma "arbusto de segunda ordem no jardim das Musas". Partimos aqui de outra concepção. Interessa para nós muito mais a transformação 
que os diálogos entre mundos, via tradução, compreendem, do que qualquer concepção estanque ou dialética de origem. Estamos num momento crucial, em que as grandes forças que orientam o andar do mundo se deslocam. Parece não fazer mais sentido agora traduzir poesia chinesa por meio de versões europeias, como fizeram Machado de Assis, Cecília Meirelles e Haroldo de Campos. Nem fazer o mesmo com o marubo, o krahô ou o guarani.

Nesse sentido, chamar este conjunto de ensaios aqui encadeados de poiéticas não europeias, em vez de utilizar um termo como o proposto por Antônio Risério, em Textos e Tribos, de poética extra -ocidental, tem uma razão geopolítica de ser. Como chamar de ocidental um canto inuit ou krahô, ou um canto em kicongo composto na Bahia? Assumir nosso lado não europeu sem negar o lugar que ocupamos é refazer o ocidente em termos outros. Paul Gilroy, em $O$ Atlântico negro, se inspira na diáspora negra para afirmar uma possível solidariedade translocal e transatlântica entre África e América. E o gesto poiético - ethos que se configura - que aqui propomos é o de reconhecimento da legitimidade e da riqueza de alguns desses outros mundos com os quais queremos e podemos nos solidarizar.

Ainda que dificilmente algum estudo, menos ainda este número especial, consiga abarcar a totalidade de nosso caos-mundo, conseguimos reunir uma interessante amostra das infinitas possibilidades que se encontram além da Europa. Os artigos aqui publicados representam, assim, parte dessas formas de vida como desenvolvidas, sobretudo (mas não só), por parte dos pesquisadores hoje vinculados ao Programa de Pós-Graduação em Letras Estrangeiras e Tradução, assim como por alguns de seus mais promissores egressos.

$\mathrm{O}$ artigo que abre a primeira parte - Refundações - deste número especial é de um desses egressos. Hoje pesquisador autônomo, Leandro T. C. Bastos propõe, em "Morte do Homem branco e potência-senzala: tradução em tempo de novas ontologias”, instigante leitura do intenso diálogo que vem se produzindo nos últimos anos entre tradução e antropologia. Para tal, parte do filósofo francês Alain Badiou, para quem “o Sujeito contemporâneo é 
vazio, clivado, a-substancial, irreflexivo. Aliás, Ele pode apenas ser suposto no tocante a processos particulares cujas condições são rigorosas" (12). Esse sujeito contemporâneo, "vazio e clivado", vai ser, segundo Bastos, apresentado pela ontologização da matemática, mais especificamente, da teoria dos múltiplos transfinitos, de Cantor, ou seja, nesse contexto trata-se de falar de múltiplos compostos de outros múltiplos. Após expor alguns dos axiomas e princípios da teoria de Badiou, há no artigo uma aproximação entre o sistema do filósofo francês e o de Henri Meschonnic, pois, em ambos os sistemas teríamos "uma distribuição com alto grau de liberdade, mas não dispersa, de material (os múltiplos num caso, o ritmo em outro) e uma força que é ao mesmo tempo aberta e interventora, nas respectivas concepções de sujeito". (12)

Essa aproximação permite a Bastos, entre prudentes ressalvas de que necessariamente simplifica as discussões para que sejam abordáveis no âmbito de um artigo, reconhecer que tanto em Badiou como em Meschonnic encontra-se um sujeito descentrado que aparece como parte e ao mesmo tempo como intervenção num sistema. Essa questão estaria também presente em alguns dos mais proeminentes antropólogos da atualidade, como Roy Wagner, Marilyn Strathern e Eduardo Viveiros de Castro. Aproximando o primeiro dos antropólogos aos dois pensadores franceses, propõe-se que aquilo que Wagner chama de "objetificação" e "obviação" se relaciona com o que Badiou chama de enciclopédia e determinação, assim como o que Meschonnic chama de ritmo e sujeito. De um lado, a variedade de informações e, de outro, um princípio de intervenção (em si mesmo aberto à própria variedade). Outra definição que, segundo Bastos, vai numa direção parecida é a de Marilyn Strathern, quando trata cultura e sujeito como diferentes enfoques sobre um mesmo contínuo: “...como uma constelação de elementos, cada posição gera uma elaboração posterior com um efeito de aumento ou diminuição na constelação da posição anterior" (108). Não por acaso, destaca Bastos, Strathern se volta para a mais radical demonstração da interação entre múltiplos conhecida: os múltiplos de Cantor. 
Assim produz-se nova torção que recoloca a teoria dos múltiplos transfinitos em funcionamento para a elaboração de outro entendimento possível, multiplicado e relacional, do que poderia ser o Sujeito. Nesse contexto, destaca Bastos, coloca-se a necessidade de se pensar nas ligações não apenas entre pessoas e línguas, mas entre mundos, e por isso a noção de multinaturalismo, proposta por Eduardo Viveiros de Castro, seria fundamental. E como bem lembra Bastos, esse multinaturalismo suporia uma unidade do espírito e uma diversidade dos corpos. A existência dessa diversidade, por sua vez, faz com que seja pela distância entre mundos, entre corpos, que a tradução se encaminha, sempre no fio da navalha da equivocação. Nessa perspectiva, não se trata portanto de encontrar uma referência em comum, mas sim equívocos que possam ser partilhados, já que a equivocação é a "alteridade referencial entre conceitos homonímicos". Ele "aparece ali como o modo por excelência de comunicação entre diferentes posições perspectivas" (Viveiros de Castro 250-251).

Ao se assumir a equivocação como o fundamento do gesto tradutório, o que passa a interessar é experiência compartilhada de impossibilidades e o modo como são transformadas em potência. $\mathrm{O}$ exemplo dado por Bastos é o da escravidão no Brasil. Retomando Lilia Schwarcz e Heloísa Starling, somos lembrados que, recém desembarcados no Brasil, sem referências em comum, diante da brutalidade e de uma casa-grande que tampouco podia decifrar, a população negra teve de encontrar outras maneiras de se comunicar. "Seja através dos cultos, seja por meio dos cantos e músicas, dos batuques, dos alimentos ou dos vestiários, um processo de aculturação, adaptação e tradução ocorreu nas terras do Novo Mundo e acima de tudo no Brasil" (Schwarcz e Starling 80). Nesse momento crucial, elaboram-se outros modos de existência que, não esqueçamos, podem permitir, neste momento de grandes mudanças e de esgotamento do modelo de financeirização e de rentismo da economia global, inspirar outras formas de vida fomentadas pelo que seria nossa "potência-senzala". 
O ponto de chegada de Bastos se articula com as reflexões de outro egresso dos estudos da tradução na USP. Tiganá Santana, hoje pós-doutorando no Instituto dos Estudos Brasileiros (IEBUSP), pensa a potência criadora e tradutória afro-descendente como matricial na constituição de um pensamento negro. Em seu ensaio "Tradução, interações e cosmologias africanas", o autor parte da ideia de interação como desenvolvida pelo escritor-pensador Zamenga B. e por Bunseki Fu-Kiau para, à luz de determinadas cosmologias negro-africanas marcadamente bantu, propor uma análise acerca da ação tradutória, não vinculada à dimensão mais conhecida como interlinguística, mas de uma dimensão ontológica do traduzir sempre em movimento.

Logo no início de seu ensaio, Tiganá Santana faz um reparo ao próprio título que escolhe ao observar que, mais do que cosmologias africanas, estão implicadas em suas reflexões ontologias negras. Inspirado em pensadores como Aimé Césaire, Léopold Senghor e Achille Mbembe, Tiganá Santana situa-se nessa linhagem que visa integrar cosmologias, epistemologias, espiritualidades, linguagens e filosofias que reconhecem na África subsaariana um "movimento transformador próprio da história, das águas, dos ventos e do traduzir". Ao acoplar história, vento, água e tradução como elementos de um grande movimento transformador, o autor ativa imaginação conceitual de outra ordem. Nessa chave de pensamento, uma fresta se deixa entrever para aqueles a quem for dada a sorte de intui-la.

Em seu ensaio, o autor ensina que a força ontológica primeira, Kalunga, é um conjunto de criações que transbordou o vazio (Kalunga walunga mbungi); conjunto a partir do qual as coisas passaram a ser. E, mais adiante, depois de desdobrar dimensões desse questionamento, acrescenta que

essa força matricial, por ser um conjunto de forças, ora de um modo, ora de outro, garante-nos a movência, a não concentração ontológica num sujeito, numa configuração. $\mathrm{Na}$ base do sistema kongo de pensamento, Kalunga, que, 
metaforicamente, em estado líquido, transbordou o vazio e o dominou, apresenta-se-nos como inter-ação.

A dimensão basilar da interação aí ativada faz com que a transmutação seja princípio de criação. Nesse contexto, kindoki tem grande importância, pois "KINDOKI não é outra coisa senão o conjunto das INTERAÇÕES"; cabendo ao feiticeiro "caminhar com as interações". Essa compreensão conduz ao entendimento de que "traduzir com bases feiticeiras é caminhar com as interações; é ter ciência delas". Chega-se assim ao cerne da proposta do que pode ser uma tradução negra. Nela,

\begin{abstract}
o tradutor-ndoki ou tradutor-feiticeiro é diplomata que serpenteia seu saber, ao tempo em que se especializa em segredos que não sabe; transita entre os sistemas por necessidade. Toda tradução, para um feiticeiro, será intersemiótica, dado o fato de que será, necessariamente, inter-cosmológica e de que ele lidará com frequências que geram outras formas de introjetar e manifestar mundos. Além de inter-cosmológico, tal traduzir amparado pelas interações (pela ciência florescida nas relações) é trans-cosmológico por ser trânsito entre mundos que constituem o mundo, isto é, entre as faces recíprocas do mundo.
\end{abstract}

Difícil aqui não lembrar de Oniska: poéticas do xamanismo Amazônico, de Pedro Cesarino. No capítulo 3 do livro, que se intitula "Diplomatas e tradutores: os dois xamanismos", afirma-se que a tradução é "a condição definidora do xamanismo"; o xamã é aquele que negocia com o mundo dos espíritos e aquele capaz de traduzi-lo. O tradutor-ndoki negro se move de um modo que, ainda que parcialmente, se conecta com as interações trans-cosmológicas dos marubo. Num dos muitos exemplos encontrados no livro de Cesarino, ao diferenciar os dois "tipos" de xamãs, diplomatas e tradutores, o antropólogo comenta que os kechitxo não realizam os 
deslocamentos de que são capazes os romeya e seus duplos, cumprindo a cada um papeis distintos durante o ritual.

\begin{abstract}
Nisso se distinguem os romeya dos kechitxo: estes últimos ficam sentados nos bancos kenã enquanto os yove vêm cantar através do romeya pendurado na rede. Diplomatas de gabinete, digamos assim, os kechitxo são os responsáveis por zelar pelo trânsito de pessoas através do romeya, chamando determinados yove ou duplos de mortos [...] com os quais deseja entreter relações. Os mesmos kechitxo dizem quando um yove pode ou não partir, além de serem responsáveis por expulsar os yochï que, por ventura, venham a se aproximar da maloca com seus odores e venenos repugnantes. O kechitxo mais velho é também 'como um doutor'. Coordena o evento todo sentado nos bancos e conversa com os demais, manda os kechitxo aprendizes (os pseudoxamãs) ficarem atentos para o que dizem os espíritos, dá as coordenadas ao rewepei ('o enfermeiro'), conversa com os duplos dos mortos, identificando uma determinada pessoa que chega, realiza algo como um segundo estágio tradutivo, que consiste na mediação ou transposição para os presentes daquela informação veiculada através do corpo/casa do romeya. (Cesarino 98-99)
\end{abstract}

Essas citações são pequena amostra dos complexos universos marubo e bantu com os quais Pedro Cesarino e Tiganá Santana trabalham. Em comum, um modo outro de apreender o mundo, cujos desdobramentos, plurais, inscrevem-se nos ensaios aqui presentes e em outros desses importantes pensadores brasileiros, para quem o sujeito moderno europeu não comporta as múltiplas dimensões do existir. Nessa miríade multiplicada de possibilidades de entendimento do que é traduzir destacam-se questões como a equivocação e a opacidade. Como sugere Tiganá Santana, é preciso cuidado "em relação ao não visto, ao informe, ao tempo em que nos coloca diante da imprescindibilidade de um posicionamento". 
A ação aí constrói sua força pela relação, na relação. Nessa floresta de possibilidades existenciais, nota-se "a textura de uma terra traduzida por uma árvore que traduz pássaros e ventos”, e que se vincula ao mistério de forças ancestrais. $\mathrm{O}$ cromatismo, os sons, os relevos, os movimentos desse desenho pluridimensional, do que é chamado no ensaio também de "texto sinestésico", forma comunidade assim como o faz a árvore. Ainda que haja permanente transmutação, os atravessamentos são fortes, pois há também raiz. A árvore da floresterra é corpo sem órgãos biodiverso, e não se espalha como a gramínea, rasteira planta rizomática. A árvore e a floresta pressupõem profundezas.

Outro mergulho profundo aqui proposto é pela poesia de Jalal Uddin Rumi. Leandra Elena Yunis, hoje pesquisadora vinculada a grupos de estudos na UnB e na Unifesp, é também egressa da USP. Em seu estudo, "O orientalismo na tradução da poesia persa sufi", parte das reflexões de Edward Said reconhecendo que uma de suas grandes contribuições foi "a detecção do construto ideológico orientalista pelo qual se estabeleceu uma alteridade tão desigual na representação dos povos asiáticos e africanos pelos europeus". Sua informada reflexão retoma a história dessa invenção europeia do Oriente. Yunis destaca que nessa divisória conceitual, "que é ideológica e sob diversos prismas controversa, há ainda o problema da representação histórica, marcada em grande parte por periodizações cronológicas estabelecidos para fins didáticos, tais como a idade antiga, medieval e moderna". Entre outros exemplos, recorda a reconhecida superioridade cultural e científica de Bagdá em relação à Paris entre os séculos VIII e XII. O resultado é que o Oriente "é adquirido tão literal e tão amplamente quanto possível pelo Ocidente que o domestica filtrando-o através de códigos reguladores, classificações, espécimes, revistas, dicionários, gramáticas, comentários, edições, traduções, todos os quais formam um simulacro do Oriente" (Said 232).

Esse simulacro seria especialmente válido para a tradução da poesia persa sufi, "pois além do filtro orientalista há outro que precede toda a abordagem da mística islâmica”. A explicação dada por Yunis é especialmente esclarecedora: 
Nas traduções dos tratados sufis, por exemplo, há abundantes transliterações que parecem produzir uma estrangeirização aparentemente contrária à domesticação linguística, um mecanismo tipicamente orientalista de assimilação auto projetiva. Entretanto, esse procedimento revela justamente o problema espinhoso da transposição conceitual: no caso dos termos herméticos sufis, descobrimos serem os vocabulários místicos formados por empréstimos linguísticos que requerem longos parágrafos explicativos ou por traduções veladas e tergiversadas de léxicos filosóficos e místicos derivados de outras tradições culturais. O que os orientalistas fazem (ao menos os britânicos) é deixar o problema prudentemente irresolvido. Com isso, entretanto, se estabelece uma mistificação dos termos que sobrevive como um modus operandi do orientalismo acadêmico que se estende ao pseudo-academicismo de engajamento místico.

Após expor detalhadamente impasses da historiografia religiosa islâmica com sua lógica circular e simbólica - que, segundo Pierre Lory, Henry Corbin chamou de hierohistórica - , usando como exemplos diferentes traduções e comentários da poesia de Jalal Uddin Rumi e Omar Khayyam, Yunis afirma que "a dominação árabe foi tão problemática em termos ideológicos quanto a dominação europeia, a conversão de autores céticos ou ateus em místicos declarados". No que concerne a tradução da poesia Sufi: "enquanto a abordagem orientalista estabelece uma historicidade assimétrica, na qual se subentende que o sufi é a-histórico, a perspectiva islâmica assimila tudo à sua circularidade hierohistórica”. A dupla equivocação (europeia e islâmica), sobretudo controlada por filtros ideológicos, obliterou o fato de que, como ressalta Yunis, "a cultura persa nativa não é originalmente semítica nem islâmica, mas indo-ariana e zoroastriana". Essa compreensão faz com que emerjam importantes distinções entre o zoroastrismo e o islã. Dentre as muitas diferenças: a relação intuitiva com Deus do primeiro e de submissão do segundo; a centralidade da visualidade para o primeiro e da oralidade para o segundo; ou ainda a relevância da metafísica grega para os persas. 
Yunis não se furta às dificuldades de tais questões e propõe uma original poética do traduzir informada pelas questões acima. Para a autora,

\begin{abstract}
uma das formas de balizar essa pendular oscilação no processo tradutório da poesia persa talvez seja mantendo a atenção na dinâmica das historicidades envolvidas nos diferentes processos tradutórios e, sobretudo, na consciência de que a tradução restaura um elo de ressignificação histórica da obra que pode ocultar ainda mais os sentidos históricos latentes ou trazê-los à luz.
\end{abstract}

Nesse movimento pendular, para que imagens e conceitos persas sejam dotados de valor ao mesmo tempo contextual e revalidados historicamente para o presente, em termos propriamente estéticos, "é preciso que o tradutor tente ao menos ver no sentido zoroastriano e ouvir no sentido islâmico".

É, pois, nesse duplo movimento diacrônico e sincrônico, ciente de que há zonas de opacidade onde se instaura o mistério, nesse duplo gesto compreensivo de aproximações e de distanciamentos, que o tradutor, se lograr a produzir fortes atravessamentos, revivifica, por meio do que chamamos de poiética transtemporal, o poema ou o canto. Em Yunis, é por meio do que nomeia de Samatradução que se instaura esse gesto. Com esse neologismo, baseado no termo árabe "samá" (audição), a autora indica uma metodologia elaborada para a recriação poética da poesia persa sufi. Com ela pretende-se combinar gnose intuitiva, abordagem histórica e interação lúdica com o campo imaginário e semântico do poema. No corpo do artigo ela apresenta um dos resultados dessa sua poiética transtemporal e, em sua conclusão, dedica seu texto ao Professor Michel Sleiman que, por meio dos estudos corânicos, tem dado consistente contribuição para os deslocamentos ontológicos que nesse número especial se apresentam e que, a nosso ver, são imprescindíveis para a ampliação de nossa capacidade imaginal. 
É de Michel Sleiman, reconhecido professor e tradutor de poesia árabe, o artigo "Estudos corânicos e tradução: o texto original". Fruto de profunda e longa pesquisa a respeito do Alcorão e de suas traduções, esse ensaio seminal é muito provavelmente a base de pesquisa de fôlego que aí se fundamenta. Debruçando-se sobre um dos mais sensíveis textos existentes, Sleiman propõe cuidadosa retomada de distintos modos de concepção do Alcorão. Começa pela história da circulação de trechos traduzidos do Alcorão em cartas enviadas pelo Profeta aos governantes de outros reinos conclamando-os a aderirem à nova ordem divina, cartas essas que seriam lidas nas línguas de seus destinatários copta, persa, etíope, bizantino, no século VII; e, em seguida, comenta que, já para finais do século VIII, a ortodoxia abássida apressa-se a fechar de vez as portas para a possibilidade/legitimidade de tradução do Alcorão por se tratar de fala direta de Deus descida à humanidade por intermédio da voz do anjo Gabriel ouvida pelo Profeta.

Advém dessa discussão o sempre retomado argumento, por parte de certos intelectuais, da intradutizibilidade; cabendo à tradução o papel de mero comentário. Para ilustrar esse tipo de argumento, Sleimam cita Abdul-Raof para quem:

\begin{abstract}
O discurso do Alcorão é um cenário linguístico caracterizado por um arco-íris de características sintáticas, semânticas, retóricas, fonéticas e culturais diferentes de outros tipos de discurso árabe. Através da coalizão dessas características, uma textura linguística única se desdobra para o leitor dominada pela harmonia nos níveis sintático, semântico e prosódico: de fato, a interfertilização entre esses elementos não poderia ser melhor alcançada. A maioria desses recursos é estranha às normas linguísticas de outras línguas. (92)
\end{abstract}

A esses argumentos de ordem linguística que, como também assinalam Tiganá Santana e Leandra Yunis, não dão conta da complexidade histórica, ontológica e intersemiótica que se manifesta na transmutação dos corpos (textuais ou não), Sleiman acrescen- 
ta outros de ordem retórico-intertextual. Depois de revisitar parte importante da bibliografia que se debruça sobre o estabelecimento do Alcorão, o pesquisador ressalta que estudos revisionistas mais atuais aceitam que "o Alcorão possa ter-se debuxado nos estandardizados caracteres aramaico-siríacos [...] neste caso, o Alcorão seria uma tradução num árabe que se pretende claro”.

Esse longo e informado arrazoado permite a Sleiman compreender a tradução do Alcorão como "uma nova síntese de cultura, em constante interação com outros sistemas de cultura e de fé". Tal consciência faz com que caiba ao tradutor dispor as camadas do processo formativo-compositivo do corpus corânico "em retrospectiva relacional com as narrativas bíblicas, especialmente as semíticas, embora também não se deva descuidar os referenciais egípcio-copta e zoroástrico-iraniano". A tarefa do tradutor comentador contemporânea é, nessa perspectiva, de precisar sentidos na densidade histórica dos referenciais.

No final do ensaio, à tarefa acima mencionada, o autor acrescenta outra. Ao argumentar que a tradução, por oferecer texto paralelo, dependente de seu par, se faz possível. Ao fazer-se "confere nova realidade a um texto definido em instância anterior, em disposição sígnica outra, mas completiva, com relação a ele no tempo e no espaço". Para fundamentar seu argumento, Sleiman retoma a ideia de Haroldo de Campos de que a tradução "pode estabelecer uma relação isomórfica, ou paramórfica" com o texto de partida. Conforme Sleiman, nessa relação paramórfica há "significados equivalentes, em relação de interdependência, produzidos por criação de estruturas diferentes". E logo em seguida complementa:

ou, dito de outro modo, a tradução pode instaurar uma forma independente da original mas que se mostra capaz de manter com o texto anterior uma relação dialogal, na qual o tradutor reavalia significados de vária natureza: signos verbais, sonoros, prosódicos, culturais dispostos na pauta singular da língua da tradução. 
A nosso ver, em seu "outro modo de dizer", Sleiman produz interessante deslocamento em relação a Haroldo de Campos. Se para o poeta paulistano, a poética tem com dominância a forma e a estrutura, na releitura de Sleiman o complexo em jogo se amplia passando a ser atravessado mais intensamente por dimensões retórico-intertextuais e culturais. No revelador exemplo que coloca na nota 15 de seu texto, ao traduzir o versículo 5, 3 do Alcorão (transliterado por lyawma 'akmaltu lakum dinakum wa-'atmamtu 'alaykum ni'mati wa-radaytu lakum al'islama dina.) como "Hoje Eu completei-vos o credo e culminei-vos Minha Graça e alegreivos com um credo de paz", Sleiman em seguida comenta:

Tradução e grifos nossos: os sublinhados salientam a repetição morfossemanticossintática que se observa nos três segmentos; os negritos salientam as repetições sonoras nos três segmentos; os primeiros segmentos repetem 8 sílabas e o terceiro amplia para 10, obtendo-se acréscimo de $25 \%$ - o versículo árabe tem 10 sílabas nos primeiros segmentos e 12 no terceiro, observando-se acréscimo no último em $20 \%$; semântica e culturalmente o sema 'culminar' contém os semas 'completar' e 'por cima', contidos no árabe ' 'atmamtu 'ala' = 'completei sobre'; no campo da filiação linguístico-religiosa, a progressão entre 'credo', 'Graça' e 'credo de paz' marca o fim do ciclo da revelação com os acordos de paz entre Medina e Meca e demais localidades durante a expansão na Península Arábica empreendida sob a égide do Profeta.

Vê-se que suas observações não se atêm a aspectos formais, e consideram, por exemplo, o campo da filiação linguístico-religiosa. Nesse sentido, acreditamos que a densidade e o alcance das reflexões basilares que informam o projeto de retradução em curso, pelo modo como são apresentadas por Sleiman, tendem mais para uma poiética transtemporal do que para uma poética sincrônica como elaborada por Haroldo de Campos. 
Projetando-nos para um espaço onde o tempo é de larga escala, Julio Reis Jatobá nos leva à Ásia em "Poéticas do traduzir $a$, na e para a China: uma proposta". Professor do Departamento de Português na Universidade de Macau, Jatobá faz inédito apanhado em português sobre aqueles que podem ser considerados os grandes e atuais pensares da tradução poética na China. Após referir-se aos dois grandes momentos da milenar história da tradução na China e ciente da impossibilidade de tratar de assunto tão vasto nesse seu ensaio, o pesquisador opta por buscar outras linhas que conduzam a uma "poética do traduzir na China" ou uma "poética de traduzir a China”. Essa distinção, que já aparece no título, parte do entendimento de que duas grandes forças são operantes na construção do discurso de uma "chinesidade" literária. São elas, segundo Pozzana e Russo (9): zhongguoxing, "as determinações particulares da língua e da cultura chinesa (a sua diferença com as outras línguas e culturas)"; e zhongwenxing, "os processos de verdade artística que vêm de, e voltam para, este particular espaço linguístico-cultural”. Considerando essas "determinações" e esses "processos de verdade artística", elaborados inicialmente pelo poeta chinês Yang Lian, como lados opostos mas complementares da literatura chinesa, Jatobá propõe, como tradução a esses dois termos, o singular "chinesidade" para zhongguoxing e "chinesidades" para zhongwenxing. Essa distinção é fundamental, pois, prossegue Jatobá,

falar sobre língua chinesa implica falar de toda uma tradição e transformação cultural da China; assim como falar de sua formação territorial e de sua força como polo irradiador poético, filosófico, linguístico e tecnológico (Jatobá 213).

Nessa múltiplas camadas que constituem a(s) chinesidade(s), encontra-se a igualmente complexa noção clássica de "arte" como um subproduto da tradição literária, fazendo com que haja intrínseca relação entre caligrafia-poesia e poesia-imagem. A ela Jatobá soma ainda a ambiguidade e opacidade da "identidade da literatura 
traduzida" no contexto literário chinês. Para resumir a questão, retoma a seguinte síntese de Zhang:

\begin{abstract}
A identidade da 'literatura traduzida' tem sido uma questão ambígua e opaca no contexto literário chinês, devido ao fato de que a literatura traduzida na China era tida como uma transformação meramente técnica e simples a nível linguístico, daí que a literatura traduzida não passava de uma parte da 'literatura estrangeira'. Nesta classificação, as complexas atividades de tradução foram simplificadas, sendo descartadas suas próprias características distintas. (83)
\end{abstract}

Como contraponto a esse discurso hegemônico, no último quarto do século XX e na virada para o século XXI, surgem na China duas outras abordagens da tradução poética: Traduto(meio)logia e traição criativa. Propostos ambos pelo professor de literatura comparada e de estudos da tradução da Universidade de Estudos Internacionais de Shanghai Xie Tianzhen, esses conceitos, informa Jatobá, ainda que não sejam aceitos por todos, são relevante inflexão no campo. Traduto(meio)logia é o termo cunhado por Jatobá para traduzir o 译介学 (yì jiè xué), proposto por Xie Tianzhen em 1999. Como constata o pesquisador brasileiro, literalmente, 译学 (yì xué) significa Estudos da Tradução ou Tradutologia e 介(jiè) estar entre. Com o intuito de tentar chamar a atenção para a pergunta: "em que meio se encontra um pensar a tradução na China que discuta e integre a guinada cultural na tradução e a guinada da tradução nos estudos culturais", Xie elabora o termo traduto(meio) logia, permitindo não mais visar a tradução literária pelo viés da transformação linguística, mas pelo viés da macroperspectiva da literatura comparada. Desse modo, segundo Jatobá,

a traduto(meio)logia toma as traduções deixadas pela história como fato consumado e dedica-se a investigar e analisar 
os fenômenos linguísticos nessas traduções como recursos para estudos literários ou culturais.

A “traição criativa", nesse contexto, complementa, é aquela que produz relação forte entre o que dispõe o texto do autor, o tradutor (que propõe "traições criativas"), o leitor (que, individualmente, dá sentido à "traição") e o ambiente de recepção (que, coletivamente, consagra as "traições").

A esse modo de conceber uma teoria complexa da recepção a partir de sua(s) chinesidade(s), somam-se ainda, segundo Jatobá, duas poéticas brasileiras de se traduzir a poesia chinesa: a metáfora do Taotie e a paralaxe tradutória. A primeira, formulada pelo poeta e tradutor Ricardo Portugal em diálogo com a antropofagia modernista, não se quer um conceito prescritivo para o ato tradutório, mas sim uma espécie de "emblema", imagem-ícone necessariamente exagerada. Conforme Jatobá, o Taotie é um lendário monstro canibal da mitologia chinesa e, em função do seu voraz apetite, é referido como "besta glutona" ou "ogro glutão". De acordo com as lendas, apesar de mastigar corpos não era capaz de degluti-los, cuspindo-os após deformá-los com sua mastigação. Inspirado por esse emblema, Portugal, em entrevista concedida ao autor do artigo, pondera:

Em minha prática de tradução, procuro conscientemente produzir objetos que tenham formas próprias e únicas, diferenciadas, utilizar-me dos recursos formais e referências semânticas disponíveis em minha cultura para reproduzir os significados do autor original, o efeito da forma que ele construiu em sua cultura. O objeto tem que ser estranho o bastante, para que seja único. Por exemplo, traduzo Du Fu procurando, por vezes, fazê-lo soar como "um Camões estranho".

Ao reconhecer no trabalho de reescrita o que ele tem de deformador e de estranho, ao mesmo tempo em que é espaço de construção de formas próprias e únicas, Portugal situa-se, assim 
entre aqueles que já não interpretam a devoração como assimilação. A dificuldade de se absorver o outro, dada a opacidade indigesta que o constitui em sua alteridade, leva à vomição do mastigado. $\mathrm{O}$ resultado é inevitavelmente um fazer soar em português estranho.

Em consonância com Portugal, essa irredutibilidade do outro leva Jatobá a propor abordagem que nomeia "paralaxe chinesa". Partindo de Slavoj Žižek, para quem a palavra paralaxe, ou lacuna paraláctica, pode ser interpretada como

a ilusão de poder usar a mesma linguagem para fenômenos mutuamente intraduzíveis e que só podem ser compreendidos a partir de uma espécie de visão em paralaxe, de um ponto de vista sempre mutável entre dois pontos entre os quais não há síntese nem mediação possível. (14),

Jatobá considera o paradoxo da simbiose capitalista-comunista que faz com que a China invada o Ocidente e seja, ao mesmo tempo, invadida por ele, "a concretização do modelo global-consumidor criado pela Inglaterra, divulgado nos quatro cantos do mundo pelos EUA e, enfim, posto em prática pelo poderio industrial e populacional da China".

No que concerne a tradução, o pesquisador brasileiro retoma sua explicação de que na poesia chinesa há intrínseca relação entre caligrafia-poesia e poesia-imagem, para defender que,

no processo tradutório, os textos de partida e de chegada são como fotografias em que um conjunto de cascas visíveis e sensíveis surgem pertencentes a tempo-espaços naturalmente não reproduzíveis, quer no contexto de origem, quer no contexto traduzido.

Caberia, assim, ao fotógrafo-tradutor sentir o impacto-efeito da imagem "original" verbalizada e não-verbalizada e, a partir dela, 
produzir, com sua bagagem estética, (inter)semiótica e gramatical, nova imagem. Naturalmente diferente da "original”, ela seria a única capaz de reproduzir o "impacto-efeito" das imagens do texto de partida. Tais reflexões levam Jatobá a concluir que “é a visão em paralaxe do tradutor que compreende os textos de partida e de chegada em uma só humanidade possível".

O filósofo, sinólogo e helenista François Jullien nota que "o humanismo confuciano revela-se em estreita afinidade com o humanismo latino" (102). Não é, pois, de se estranhar que uma poética da paralaxe chinesa se coloque como possiblidade para se pensar as relações literárias e culturais entre China e Brasil, uma vez que os dois países, em seu discurso nacional (e/ou imperial) se reconhecem como sendo de matriz confuciana e de matriz cristã e latina, respectivamente. Assim como Jatobá, Jullien nota que essa aproximação entre distintos mundos é inevitavelmente oblíqua, uma vez que "não projetamos senão uma universalidade transversal ao detectar nas duas culturas um ponto de recorte possível a partir do qual elas se instalem e se alinhem" (Jullien 115): caligrafia-poesia | poesia-imagem | fotografia-tradução, na instigante proposta de Júlio Jatobá.

No estudo supracitado, Jullien também indica que nem Índia, nem Japão, nem a África, nem os países muçulmanos costumam ter o ímpeto de conceber-se como pontos de partida de um universal humano. É a ideia de comunidade que definiria cada qual em sua especificidade. E refletir sobre a comunidade é necessariamente debruçar-se sobre o "comum”. Conforme Jullien,

se o comum é o que partilho com alguns, é também, em virtude disso, seguindo essa linha de partilha, mas que vale também como demarcação, o que exclui os outros. [...] Comum, portanto, é um termo de dupla face: é ao mesmo tempo inclusivo-exclusivo" (42). 
O ex-comungar, forma mais fechada do "comunitarismo" tão em voga na política atual, tem como seu contraponto, sugere Jullien, sua raiz типиs - responsabilidade do dom-dever. Dessa maneira,

se a comunidade se concebe sob o signo do munus, da dívida e do dom, a relação de pertencimento à qual se fiaria de bom grado o sentimento comunitário, e que o ampara, vê-se saudavelmente invertida e dependente" (Jullien 43).

Nessa perspectiva, conclui Jullien, "a comunidade tem como vocação não se cerrar mas se descerrar" (ibidem). As leituras aqui propostas, acreditamos, situam-se nessa perspectiva; também as que se debruçam sobre poéticas ameríndias.

Com efeito, um dos espaços geográficos e de imaginação que nos é mais próximo e mais distante é o do mundo ameríndio. Patrick Rezende, doutor pela Pontifícia Universidade Católica do Rio de Janeiro, traz importante contribuição a respeito em "Para além do Oral e do Escrito: o caso das reescritas kotiria", cabendo a ele, neste número, garantir, juntamente com Guilherme Gontijo Flores a imprescindível presença das culturas ameríndias na parte dedicada às "Refundações". Rezende inicia sua reflexão tocando em questão fundamental: as sociedades indígenas são ágrafas? Usando como exemplo a arte Kusiwa, representações gráficas características dos Wajãpi, o pesquisador chega ao entendimento de que:

[...] os povos originais, independentemente da presença de um alfabeto, sempre foram capazes de constituir as memórias de seus povos por meio de complexas tecnologias discursivas. Em outras palavras, o que buscamos afirmar é que os indígenas sempre foram sujeitos históricos que se valem de uma sofisticada rede de processos semióticos que permitem a materialização de formas de memória que agem sobre o coletivo e, consequentemente, possibilitam a produção de seus arquivos. 
Logo em seguida, Rezende retoma Tania de Souza para acrescentar que "é preciso se estender a noção de arquivo para além do limiar da escrita" (50). Assim, a construção de sentidos deve ser compreendida em seus diferentes níveis de interações e interlocuções, além de "variações na impostação de voz, variações de entoação, o uso inesperado do silêncio e o uso da repetição" (Menezes de Souza 203).

Essas considerações levam à discussão sobre a importância do som das palavras para muitas línguas indígenas na construção do sentido. Como exemplo, Rezende cita os cantos dos Bakairi. Como observa Souza, os Bakairi mantêm a tradição de cantar suas músicas ainda que desconheçam o que cada palavra signifique. Para eles, "não importa a tradução. O que importa é o sentido que se inscreve e se reinscreve ao longo da história" (46). Entretanto, "a ausência de significado não resulta na ausência de sentido, instaura-se, então, a significância, quando o sentido se institui pelos significantes, e não pela imanência do significado" (ibidem).

Essas considerações nos permitem refletir sobre como, nesses regimes conceituais de imaginação, há formas de escritura para além da escrita alfabética, e de como as memórias são constituídas por meio de variadas formas de linguagem, para além da dicotomia escrita versus fala. Outro exemplo é a Série Kotiria coleção trilíngue com quatro livros publicados, entre 2014 e 2015, e que trazem algumas das diversas narrativas dos Kotiria (Wanano). Depois de retomar a longa história do registro dessas narrativas na década de 1970 feita pela antropóloga estadunidense Janet Chernela, Rezende descreve o trabalho em equipe que possibilitou a publicação das narrativas, todas as quatro ilustradas por um indígena, Miguel Cabral Júnior.

A análise desse processo de apropriação da escrita alfabética e do projeto editorial pelas sociedades ameríndias é interpretado por Rezende, em termos derridianos, como um modo de suplementação. Como o pesquisador destaca: "suplemento (supplément) não significa aqui uma forma de complementar algo, como se a escrita alfabética fosse um modo de se representar a fala. Suplementar refere-se à ideia de se adicionar algo que já está completo em si mesmo". É 
o empoderamento dos indígenas que interessa, de forma a abalar os pilares das hierarquizações e das ideias binário-opositivas europeias, para, desse modo, voltar-se para a alteridade. Alteridade, aliás, sobre constante ataque e ameaça. Como tristemente ilustram, salienta Rezende, as agressões cometidas pelo atual presidente do Brasil em direção a esses povos: em 1998, este já declarava que "a cavalaria brasileira foi muito incompetente. Competente, sim, foi a cavalaria norte-americana, que dizimou seus índios no passado e, hoje em dia, não tem esse problema em seu país" ${ }^{1}$; recentemente disse que "enquanto eu for presidente não tem demarcação de terra indígena" 2 .

Ainda que estejam sobre constante ataque, os povos indígenas seguem contribuindo para o enriquecimento e deslocamento de nossa imaginação conceitual, como bem demonstra o prodigioso ensaio de refundação de Guilherme Gontijo Flores, reconhecido poeta e tradutor, também professor da UFPR. Em "um walkietalkie na encruzilhada das águas: traduzir e cantar a poesia xamânica marubo", crepitando no fogo da invenção, Flores faz desabrochar ímpar reflexão sob as sendas da retradução. Mobilizando ampla bibliografia tantos dos estudos da tradução e dos estudos clássicos como da antropologia, Flores vai, a partir da descrição de uma vivência pessoal de descoberta dos cantos marubo traduzidos e de contato com seu tradutor, o antropólogo e escritor Pedro Cesarino, compondo sua narrativa. Ele começa pelo dia em que manifestou seu desejo a Cesarino de retraduzir e performar em outros contextos esses cantos. Ele lembra do silêncio de Cesarino na ocasião e deixa o leitor em suspense...

A reflexão prossegue por outros caminhos, Gontijo retoma então Guillaume Boussard, tradutor de Lucrécio ao francês em padrões rítmicos hexamétricos e também impressionante performer de poemas em latim e francês, quando este diz que, se alguém quiser fi-

${ }^{1}$ In The New York Times: https://www.nytimes.com/2019/08/27/world/americas/ bolsonaro-brazil-environment.html.

${ }^{2}$ In Carta Capital: https://www.cartacapital.com.br/politica/bolsonaro-enquanto-eu-for-presidente-nao-tem-demarcacao-de-terra-indigena/. 
car fora de si, não precisa necessariamente de drogas: basta recitar com vigor uns cinquenta hexâmetros gregos ou latinos, que a ação corporal garantiria um movimento rumo ao transe. Guiado por essa consciência corporal da voz e do gesto, Flores acopla o transe grego ao xamanismo ameríndio evocando os Araweté de Viveiros de Castro e, sobretudo, o monumental Queda do céu, de Davi Kopenawa \& Bruce Albert. O complexo enunciativo que se produz nesse contexto em que corpos e espíritos circulam é resumido assim: "o xamã canta um canto que não é seu e, ao ouvi-lo, aprende o saber que vem dos espíritos da mata, escuta o que seu corpo alterado canta e nesse curto-circuito age sobre si e sobre os outros". O agenciamento aqui descrito não deixa de se conectar com a compreensão de Tiganá Santana para quem a transmutação é princípio de criação, cabendo ao feiticeiro "caminhar com as interações".

Flores, em seguida, informa sua reflexão por meio da etnopoética de Jerome Rothenberg e do pianista e tenor Jeremy Dutcher. Guardadas as importantes distinções entre essas duas poiéticas, ambas produzem possibilidades de diálogos entre mundos que interagem nas e pelas diferenças. É nesse contexto que reaparece $\mathrm{Ce}$ sarino com uma resposta: haveria um canto, atribuído pelos xamãs marubo ao "duplo" do antropólogo que poderia ser reinventado por Flores. Cesarino poderia autorizar tal reinvenção por este canto específico ser, de algum modo, (d)ele Cesarino.

O cuidado com que Gontijo se aproxima das sensíveis questões aí envolvidas se manifesta na reveladora citação que faz do epílogo do livro de Cesarino:

Descubro aí nesse iniki que, além de ter um duplo que me ajuda a pensar, também os tios foram responsáveis pela minha capacidade de entender os cantos. Eles sopraram ou enviaram tal saber para mim através dos inaladores de rapé. O rewe não é apenas um soul catcher, mas também um transmissor de conhecimento, de chinã, que é também palavra utilizada para designar os duplos. Ora, conhecer significa aqui personificar. Sangama, o índio piro sobre o 
qual escreve Peter Gow em An Amazonian Myth ans its History, via por trás das letras uma mulher-espírito de boca vermelha, brilhante com seu batom. Por conta disso, ele conseguia decifrar os livros dos brancos e impressionar os seus parentes analfabetos. Por uma inversão simétrica, o antropólogo que vos escreve parece ter aprendido esses cantos por intermédio de seus tios-espírito e, mais adiante, de seu próprio duplo irmão. Aprender é tornar-se apto para repetir, traduzir ou reproduzir os saberes de outrem; colocar-se em relação com uma coletividade e um campo de parentesco; 'ligar pensamento', enfim. (402)

Assim, a tradução poética aparece para Flores como "um modo intenso de aprendizado, como preparação para uma repetição modalizada ou diferenciada, ou mesmo diferida". É nesse espaço diferido, em viva paralaxe, como suplementação, que vão se alinhando-tangenciando, por meio de atravessamentos, as possibilidades de escuta, com os pontos surdos que implicam. Gontijo chega aí a um dos momentos altos de sua reflexão ao recuperar a seguinte citação de Rothenberg:

Por trás de tudo isto há também um motivo escondido: não apenas tornar claro o mundo do original, mas fazê-lo com alguma distância da própria canção: para refletir a canção sem o 'perigo' de apresentar alguma parte dela (a melodia, por exemplo) exatamente como conhecida: consequentemente tê-la ao não tê-la, por respeito ao senso de discrição e de localização que é tão importante àqueles a quem as canções são sagradas \& vivas. Assim as mudanças que resultam da tradução são, neste caso, não só inevitáveis, mas desejadas, ou, como um seneca me disse 'Não gostaríamos que as canções fossem parar tão longe de nós; não, as canções ficariam muito sós.' (Rothenberg 50)

A partir daí Flores depreende que, 
na relação de uma poética vocal e sagrada, na tradução de cantos sagrados, a noção de traduttore traditore se inverte: é precisamente a disposição a uma traição do senso e da forma que, por outro lado, preserva o canto de seu extravio perigoso.

A equivocação passa, assim, a ser o próprio espaço de preservação do outro em sua diferença. Faz lembrar os Bakairi, que mantêm a tradição de cantar suas músicas ainda que desconheçam o que cada palavra signifique, pois o que importa é o poder de significação que se faz reverberar. Nesse espaço de ressonâncias vai se elaborando o projeto de reencenação vocal do canto marubo. O resultado que Flores apresenta desses dois cantos de Iskõ Tae, vaká-duplo de Pedro Cesarino, a partir da voz de Armando Cherõpapa Txano, via transcrição e tradução de Pedro Cesarino, mais do que estabilização de uma forma, permanecem como partitura-em-esboço.

Na segunda parte desse número especial, que para fins práticos nomeamos "Reescritas", encontram-se ensaios que se debruçam de modo mais detalhado sobre projetos de reescrita. É claro que textos como os de Yunis sobre a poesia persa ou o de Gontijo Flores sobre os marubo poderiam se situar entre os artigos voltados à reescrita, até porque, como lembra Meschonnic, em sua Poética do traduzir, quando se trata a reunir elementos para uma poética da tradução, a teoria costuma ser o acompanhamento reflexivo, pois a experiência vem primeiro. A especificidade das reflexões aqui reunidas talvez seja que, ao estarmos diante de poéticas tão pouco visitadas, a experiência exija outra abordagem. Como aponta François Jullien, quando se coloca em relação mundos muito distantes,

verifica-se inevitável desconstruir aqui e reconstruir ali, $d e$ e re-categorizar, a despeito da iniciativa de comparar (ora, toda tradução necessariamente implica isso), deveremos igualmente des-comparar, pelo menos mediante o comentário, para deixar entrever esse resíduo de incomparável que, ao ser traduzido, foi dissimulado (Jullien 116). 
A primeira das reescritas que compõe a Parte II também (proble) matiza essa discussão. Em "Sobre a lenha, labareda sou: poética da memória em um canto ritual krahô", Ian Packer, doutorando em antropologia da Unicamp, apresenta a transcrição e a tradução da letra de um canto krahô, povo ameríndio falante de uma língua Jê e que vive no norte do estado do Tocantins. Em sua reflexão, propõe um exercício cruzado em que o comentário etnográfico enriquece a tradução e o comentário sobre a tradução enriquece a etnografia, ambos movimentos contribuindo para uma compreensão mais detalhada do texto e do contexto desse canto. Trata-se do "canto de Pootyt", reconhecido como exemplar de um dos diversos gêneros de arte verbal encontrados entre os Krahô e que constituem formas expressivas centrais em seu vasto e complexo sistema ritual.

Num dos belos momentos de seu exercício cruzado, o antropólogo retoma o contexto do canto e observa:

se no início de sua performance Pootyt se encontrava de pé, sozinho e enfraquecido pelo Frio-Noite que se abate sobre ele no pátio, enquanto seus ouvintes se encontravam deitados e aquecidos em suas casas, agora, próximo ao final do canto, ele se encontra na companhia dos cantos dos antepassados que $[\ldots]$ o aquecem como uma mulher.

E é esta transformação da condição do cantor, que leva Packer, em sua conclusão, a afirmar: "aquecido pela memória e pela enunciação dos belos cantos dos antepassados (sua lenha), o bravo cantor-Labareda crepita noite adentro no pátio da aldeia": Sobre a lenha/Labareda sou.

No artigo seguinte, o fogo se acende pela força do encontro amoroso. Intitulado "Seis sonetos darwishianos", esse ensaio da professora de literatura árabe da USP Safa A-C Jubran e do mestrando Marco Antonio Calil Machado visa apresentar e discutir a tradução de seis sonetos escritos pelo poeta palestino Mahmoud 
Darwish (1941-2008) constantes no livro A Cama da Forasteira do ano de 1998. A precisa análise apresentada de efeitos produzidos por esquemas sonoros, semânticos, formais e discursivos, assim como de suas possíveis ou não traduções à língua portuguesa, exploram proximidades e distanciamentos em relação às matrizes europeias do soneto e seus desdobramentos modernos.

Em suas conclusões, levando em conta que a arquitetura argumentativa em dois dos sonetos darwishianos coincidem com a lógica cripto-erótica do Dois-em-Um e dialético-dual, os autores destacam que o léxico conceptualizado e o jogo opositivo de metáforas derivadas geram "reenvios e curto-circuitos entre os valores do feminino-masculino, eu-lírico e interlocutor, eu-e-tu, de modo a colapsar a distância entre tais parâmetros: se os poemas começam pela dualidade da cisão, não terminarão nela". E esse "movimento de duplos recombinantes e mutuamente aniquiladores (uma síntese das antíteses...) que os seis sonetos recuperam" manifestam, em certo sentido, o próprio gesto de toda grande tradução.

O trabalho de Moacir Amâncio, poeta e professor de literatura hebraica na USP, é também o de reescrita de uma poética em língua semítica. Como o título indica, "David Fogel no centro da periferia”, o artigo se debruça sobre a obra deste poeta judeu, nascido na Rússia e morto em Auschwitz em 1944. Como assinala Amâncio, após o fim do esplendor dos tempos ibéricos medievais, dos quais os judeus participaram plenamente, sob os governos islâmicos, o renovado impulso cultural da língua hebraica somente eclodiria ao final do século XVIII, com a Hascalá ou o Iluminismo Judaico, na Alemanha. É nesse contexto que surge uma literatura hebraica na Europa.

Como atesta o ensaísta, esses autores judeus produziram, na Europa, toda uma literatura nos moldes da época, "mas em hebraico e por isso na maioria permanecem desconhecidos fora do âmbito primeiro judaico então, e hoje israelense, confinados num território quase invisível à cultura europeia". E serão justamente essas obras, notadamente a poética de Fogel, que redescobertas a partir de 1950 , contribuirão "para mudar a expressão israelense quando 
o indivíduo começaria a conquistar seu posto na paisagem cultural do país". Este caso ímpar, em que uma poética quase invisível na Europa se torna fundadora em outro continente, ao fazer com que a linguagem da Bíblia adquirisse "o sotaque da contemporaneidade", é ilustrado por cinco poemas de Fogel, retirados do livro Diante do Portão Escuro e magistralmente traduzidos por Moacir Amâncio.

No quarto artigo da parte "Reescritas", "Traduzindo os cheiros do Chiclete de Kim Ki-taek", a professora de estudos coreanos da USP, Yun Jung Im, apresenta o livro de poemas Chiclete de Kim Ki-taek, publicado originalmente em 2009 na Coreia e em 2018 no Brasil. Trata-se do primeiro poeta contemporâneo coreano traduzido para a língua portuguesa, sendo ele representante de uma poesia urbana cujos temas são comuns às populações das grande metrópoles. Apesar de abordar questões do mundo contemporâneo, as dificuldades de tradução entre línguas tão distantes implicam exigentes escolhas. Antes de se debruçar sobre essas questões de tradução, a pesquisadora faz síntese esclarecedora sobre o processo de formação da literatura coreana e da tardia adoção do hangul como meio de produção literária no início do século XX. Sua apresentação inclui também considerações sobre sua dificuldade de fazer circular e de transpor para um contexto tão distante como o brasileiro os ares da poética coreana. Dando continuidade a seu heroico trabalho, Yun traz uma das difíceis questões que teve de tratar neste que é o quarto livro que publica de tradução de poesia coreana em português - as nuanças dos cheiros.

A precisão com que descreve as nuanças ali implicadas reforçam o papel imprescindível do comentário como procedimento de desassimilação criadora para que a atenção às zonas de sombra entre línguas-culturas nos permita pensar nossos próprios impensados, concebidos aqui como aquilo que uma determinada língua-cultura não é capaz de perceber sobre si mesma. Como observa Jullien: "uma língua, uma cultura, um pensamento, em sua defasagem [écart], fornece outras apreensões - outra percepção - sobre o impensado; e sua fecundidade é medida pela potência dessa apreensão e dessa percepção" (193). O conceito de "écart", traduzido na 
edição que citamos por "defasagem", como esclarece o próprio filósofo, "é um conceito rigoroso e combativo neste aspecto: ao nos levar a sondar até onde podem ir as divergências, a avaliar a distância que se abre entre elas, ele desdobra o cultural e o pensável no seu limite" (Jullien 190-191).

No ponto de vista aqui adotado, o "écart" e o que ele implica de impensado em português, justamente por se situar na esfera do intraduzível, cruza o que foi dito até aqui sobre a equivocação via Viveiros de Castro. Em seu ensaio sobre o tema, o antropólogo propõe que "o perspectivismo indígena é uma teoria da equivocação, ou seja, da alteridade referencial entre conceitos homonímicos. A equivocação aparece aqui como o modo de comunicação por excelência entre posições perspectivais diferentes"; e, acrescenta, "a comparabilidade direta não significa necessariamente tradutibilidade imediata" (Viveiros de Castro 250-251). Ele ainda esclarece que a comparação que propõe seria "controlada" por se diferenciar do "tipo de comparação, mais frequentemente [...] implícita ou automática (e, portanto, descontrolada)" (ibidem) a que estamos sujeitos. Não estamos distantes aqui do "écart" de Jullien, para quem "o ponto de vista da defasagem [écart] desperta [...] o cultural e o pensável de sua sonolenta normatividade [...] inaugurando possíveis" (191)...

É certo que essa discussão ultrapassa o escopo deste ensaio de abertura, mesmo se é, a nosso ver, oportuno evocá-la por nos permitir, por um lado, aproximar conceitualmente um grande pensador brasileiro do mundo ameríndio e um grande pensador europeu do mundo chinês e, por outro lado, enriquecer o debate que envolve o convívio e as tensões existentes entre traduzir e comentar. Nesse sentido, outro artigo instigante é "Wang Wei e o mistério do musgo verde azulado", escrito por Antonio José Bezerra de Menezes Jr, professor de literatura chinesa na USP e por Chen Chen, professora da Universidade de Nankai na China.

Nele, discute-se as distintas traduções do poema "Lu Zhai" ( 鹿柴; “Parque dos Cervos") do famoso poeta chinês Wang Wei (699-759). Trata-se de um preciso comentário sobre a polissemia 
contida na palavra 青 (qīng), que significa “verde, azul, preto, jovem" e usada no poema analisado para qualificar um musgo. Como destacam os autores, "em vez de escolher uma cor específica como “verde” (绿 lǜ) ou “azul” (蓝 lán), o poeta opta por uma tonalidade cujo espectro vai do azul ao verde incluindo o preto". Eles aproximam essa escolha do poeta da seguinte anedota do mestre zen japonês Kakua:

Quando Kakua voltou ao Japão depois de estudar vários anos na China, o Imperador, que ouvira dizer que ele aprendera uma nova doutrina, mandou chamá-lo à sua presença para interrogá-lo sobre ela.

Quando o Imperador lhe perguntou o que era o Zen, Kakua fez uma profunda reverência, tirou das dobras de seu quimono uma flautinha, soprou uma nota, guardou o instrumento, fez nova reverência e desapareceu. Nunca mais ninguém ouviu falar nêle. (Gonçalves 205)

青 (qīng) seria, assim, uma espécie de nota plena de harmônicos verde-furta-cor. E o que interessa, por fim, concluem, é que

a riqueza e complexidade pictórica do poeta não devem ser ofuscadas pela iluminação zen, de tal modo que o poema não deixe no leitor a impressão final de um lacônico musgo, mas sim de um extraordinário jardim verde azulado.

Há, desse modo, certa mágica que se dá a ver pelo comentário, e que nenhum tradutor trouxe até agora para dentro de seu texto. A “equivocação" que esse comentário implica vai, a seu modo, "inaugurando possíveis", pois,

[...] essas defasagens [écarts], e em primeiro lugar as que encontramos na língua, devem ser consideradas como ou- 
tros tantos recursos para o pensamento. Nós mesmos, numa época de encobrimento padronizado, não temos que nos tornar 'feiticeiros' da cultura: fazendo reaparecer suas jazidas sepultadas, seguindo filões (sulcos) fecundos e abandonados? (Jullien 191)

É, por outras sendas, uma vez mais o tradutor-feiticeiro, o tradutor-xamã, que se manifesta. Aqui por meio das equivocações controladas que habitam os comentários e traduções cruzados de Ian Packer, Safa A-C Jubran, Marco Antonio Calil Machado, Yun Jung Im, Antonio José Bezerra de Menezes Jr e Chen Chen, aos quais se somam ainda os reveladores trabalhos de Pablo Simpson e de Mário Ramos Francisco Júnior.

Em “A Montezuma, poema de Engelbert Mveng”, Pablo Simpson, professor de literatura francesa da UNESP, apresenta uma proposta de tradução de poema do poeta e teólogo camaronês Engelbert Mveng (1930-1995). Tendo vivido entre 2010 e 2012 nos Camarões, Simpson conta como chegou à poesia de Mveng, destacando o fato de este ter denunciado em seus discursos o que chamou de "holocausto colonial" no momento das independências africanas e de ter pregado em defesa de uma teologia da libertação. Ao comentar o poema escolhido, o crítico observa que ali se encontra o diálogo com dois episódios do texto bíblico "[...] com o Livro de Joel [...] e com a parábola do grão de mostarda”, em ambos havendo "o sentido de uma esperança que será a de uma voz capaz de falar a todos os povos".

Simpson acrescenta que, no poema, de certo modo encena-se a noção de inculturação desenvolvida por Mveng e que visa responder à pergunta sobre a possibilidade de Deus de "comunicar aos africanos". A resposta, comenta o tradutor, "será a mesma do poema: a celebração do canto, da música, dos ritmos, do simbolismo [...] na direção de uma mensagem de fraternidade universal”. O mais interessante, informa Simpson, é que a construção desse universal, na teologia de Engelbert Mveng, "faz recuar esse diálogo às relações que identifica entre o mundo de Jesus e os egípcios. Vê 
na ética cristã da luta da vida contra as forças da morte uma herança africana". Produz-se assim rica e inusitada inversão, que leva à compreensão das preces africanas como berço de um monoteísmo "transcendente e absoluto".

Fica portanto a pergunta: precisa a África da fé cristã?

Kalunga responde transbordando o vazio...

O ensaio que encerra as "Reescritas" é do professor de literatura russa da USP, Mário Ramos Francisco Júnior. Em "Cotraduzindo a poesia transmental russa de Velimir Khlébnikov", ele explora o interessante conceito de coartação, compreendido como aproveitamento e reelaboração dos recursos recriados por Augusto e Haroldo de Campos e Bóris Schnaiderman em língua portuguesa, primeiros tradutores da língua zaúm ou transmental de Khlébnikov. Composto pela preposição russa "za" ( $3 a$ : por, através de, além de, trans) e o substantivo "um" ( $y$ : mente, inteligência), o neologismo "transmental" pode, segundo manifesto assinado por Alekséi Krutchônikh em 1921, referir-se a: a) cantos mágicos, exorcismos, encantamentos; b) "revelação" (pelo nome ou imagem) de coisa invisível - misticismo; c) criação verbal fonético-musical. Como aponta Boris Schnaiderman no prefácio a Poesia Russa Moderna:

Revolucionando o uso da palavra, Khlébnikov estudou as possibilidades novas de seu emprego. A 'língua transmental' (zaúm) era para ele algo bem concreto e preciso; os sons aglutinados não eram fortuitos, embora estivessem desligados do conceito habitual. A linguagem dos feiticeiros, dos xamãs da Ásia Central; a montagem e desmontagem de palavras; a transformação de nomes próprios em verbos, de substantivos em adjetivos e vice-versa; o registro do canto dos pássaros; a formação de palavras nas línguas eslavas em geral - eis alguns dos recursos de que se serviu. (Campos; Campos and Schnaiderman 22) 
Esse modo de encantamento da linguagem é belíssimamente ilustrado por um poema de Khlébnikov no qual explora a dupla de substantivos "tempos-juncos", formando novos neologismos e associando "tempos" e "juncos" a pássaros ou seres imaginários, como segue na tradução de Francisco Jr.:

Quando em pasárgada passavam Rápidos bandos de tempássaros, Com tempos-juncos eu brincava,
Tempículos-júnculos lançava, Tempilhos-junquilhos laçava, E uma tempríria abria as asas.

Pelo modo como traduz, Francisco Jr. torna-se ele também "feiticeiro da cultura" ao nos dar a ver jazidas antes apenas latentes de possíveis transmentais em português, polinizando dessa maneira nossa imaginação.

Criador de uma das mais potentes obras do século XX, o poeta português Herberto Helder foi desses que se deixou fecundar outramente por poiéticas não europeias. Seu trabalho de "mudar para o português" poemas de outras línguas-cultura está reunido em cinco livro: O bebedor nocturno [1961-1966], As magias [19861987], Oulof [1997], Poemas ameríndios [1997] e Doze nós numa corda [1997]. Esse trabalho costuma ser compreendido como

\begin{abstract}
a manifestação de uma preferência ou de 'afinidades electivas', que é ao mesmo tempo um retrato de família ou a invenção de uma linhagem; em suma, a cartografia de um sistema de vozes múltiplas que se afirma comunicarem entre si no que é um sistema de encontros (Gusmão 341).
\end{abstract}

No ensaio "Herberto Helder tradutor de poéticas não-europeias", juntamente como o professor de antropologia da USP e escritor Pedro Cesarino, a partir da análise de alguns poemas ameríndios, propomos discutir as implicações das escolhas de Helder e de como podem ser interpretadas pela antropologia contemporânea. 
Chamamos essa parte final do dossiê de "Desdobramentos", pois acreditamos que, ao problematizarmos uma poética de reescrita consolidada, colocamos em prática criticamente os princípios expostos nesta recolha. Esse processo foi possível pela identificação de alguns textos de partida utilizados por Helder que permitiram notar que ele em geral opta por um processo de domesticação sintática e normatização linguística. E mesmo quando, em caso isolado envolvendo narrativa huni kuin, retoma a "desarrumação" que encontra no texto de partida, o faz pelo viés da poesia moderna europeia. Diante do exposto,

\begin{abstract}
[...] é curioso e sintomático que esse olhar etnocêntrico tenha sido tomado como o seu avesso pela crítica, que considera as traduções de Helder como inventivas quando não exatamente o são [...] Com isso, forma-se uma imagem influente de Helder tradutor alternativo e inventivo, por oposição ao cânone, que corresponde mais bem a uma espécie de imagem projetiva e de expectativa estética deste cânone sobre um 'outro' poético que não encontra correspondência em uma alteridade de sentido efetiva.
\end{abstract}

E a equivocação, "alteridade de sentido efetiva", como vimos, produz-se por meio de poiéticas da tradução transtemporais, em que o exercício cruzado de traduzir e comentar formam um complexo de heterogeneidades normativas. O mosaico que se desenha ganha contornos ainda mais vivos se, como neste número especial, mundos diversos se solidarizam translocalmente, numa dinâmica que lembra Marilyn Strathern quando trata cultura e sujeito como diferentes enfoques sobre um mesmo contínuo; como uma constelação de elementos na qual cada posição gera elaboração posterior com efeito de aumento ou diminuição na constelação da posição anterior. Produz-se assim uma malha em que "as propriedades lógicas da conexão de afinidade" fazem com que "as partes envolvidas encontram-se unidas por aquilo que as divide, ligadas por aquilo que as separa" (Viveiros de Castro 
261), gestando, na tensão do contato, ao repensar seus possíveis, modos de existência.

A adoção de uma perspectiva constelar - ou se preferirmos, com Glissant, em arquipélago - , e o convívio com outras ontologias que implica, permite expandir consideravelmente a compreensão dos modos de atravessamento e, em certo sentido, dimensionar sua potência criadora. Em "O núcleo pivotante da voz", o professor de teoria literária da USP, Roberto Zular, parte do modo de funcionamento da voz nos discursos políticos recentes no Brasil para repensar a noção de homem cordial, tomada como pivoteamento constante da voz entre o privado e o público, a amabilidade e a violência e, em todos os casos, permanecendo como o núcleo do funcionamento do poder. Essa forma de funcionamento, conforme o pesquisador, está ligada a certo modo de conceber a voz de Deus e sua hipóstase política, mecanismo fundante do processo colonial.

No entanto, prossegue Zular, a poesia brasileira tem assumido esse pivoteamento para apontar outros modos de funcionamento da voz visando potencializar e traduzir poeticamente, por exemplo, os efeitos do complexo oral canibal apontado por Viveiros de Castro a respeito do mundo ameríndio ou as dinâmicas próprias do discurso negro. Esses outros modos de existência da voz, colocados em variação, produzem uma nova dinâmica do espaço poético como partilha e dissenso. Nelas, assume-se o pivoteamento e a variação como lugar de emergência de outra ética da voz e de (re)conhecimento dos mundos que ela coloca em jogo. Assim, aquilo que aparece em muitos discursos modernos como "déficit" da cultura brasileira em relação à cultura europeia, passa a ser interpretado não apenas como corolário de nossa "má formação", mas como sintoma da emergência de outros modos de existência da voz. Assim, ao se dispor à equivocação pelo convívio com ontologias ameríndias, certos poetas contemporâneos brasileiros acionam outro regime conceitual. Conforme Zular:

Nesse regime de alteridade radical são os mundos que atravessam as vozes e cada voz é a possibilidade de composição 
de outros mundos em permanente negociação. Daí o xamã ser essa espécie de tradutor, de embaixador da relação entre os mundos metamorfoseados na multiplicidade enunciativa que agencia.

É claro que os modos como esses atravessamentos se manifestam em poéticas urbanas escritas por brancos letrados não são os mesmos, ainda que possam ser agentivamente férteis. Trata-se, desse modo, conclui Zular,

de experimentar o poema em sua ontologia variável que reverbera um devir-negro, devir-índio, devir-mulher, o próprio devir como espaço metamórfico de co-determinação recíproca que coloca aquilo que chamamos de literatura em uma potente variação ontológica.

Acolher essa reflexão como derradeiro desdobramento neste número especial ilustra a força contida nessas poiéticas não europeias e de como, com elas, é possível povoar nossos corpos e nossos regimes conceituais de imaginação.

\section{Referências}

Badiou, Alain. O Ser e o Evento. Tradução: Maria Luiza X. de A. Borges. $1^{\text {a }}$. Ed. Rio de Janeiro, João Zahar Editor Ltda, 1996.

B., Zamenga. Kindoki: source des philosophies et des religions africaines. Kinshasa: Centre de Zabatologie, 1996.

Campos, Augusto, Campos, Haroldo e Schnaiderman, Boris. (org.) Poesia Russa Moderna. $6^{\mathrm{a}}$ ed. rev. e ampl. São Paulo: Perspectiva, 2001. 
Cesarino, Pedro de Niemeyer. Oniska: poética do xamanismo na Amazônia. São Paulo: Perspectiva/Fapesp, 2011.

Fu-Kiau, Kimbwandende kia Bunseki. African cosmology of the bantu-kongo: principles of life and living. Nova Iorque: Athelia Henrietta Press, 2001.

Gilroy, Paul. O Atlântico Negro: Modernidade e Dupla Consciência. Rio de Janeiro: Editora 34/UCAM/Centro de Estudos Afro-Asiáticos, 2002.

Glissant, Edouard. Poétique de la Relation. Paris: Gallimard, 1990.

Gonçalves, Ricardo Mário. Textos Budistas e Zen-Budistas. São Paulo: Editora Cultrix, 1967.

Kopenawa, Davi \& Albert Bruce. A queda do céu: palavras de um xamã yanomami. Tradução de Beatriz Perrone-Moisés. São Paulo: Companhia das Letras, 2015.

Jatobá, Julio Reis. Poesia e (in)traduzibilidade na língua chinesa. Scientia Traductionis, Florianópolis, v.13 (2013): 213-223. Disponível em: https:// periodicos.ufsc.br/index.php/scientia/article/view/30271. Acesso em: $16 \mathrm{de}$ setembro de 2019.

Jullien, François. $O$ diálogo entre as culturas: do universal ao multiculturalismo. Tradução André Telles. Rio de Janeiro: Zahar, 2009.

Lory, Pierre; Viellard-Baron Jean-Louis. “Temps spirituel et hiéro-histoire selon Henry Corbin: une phénoménologie de la conscience psycho-cosmique". Henry Corbin et le comparatisme spirituel, Paris, p. 25-37, 2000.

Meschonnic, Henri. Poética do traduzir. Tradução de Jerusa Pires Ferreira e Suely Fenerich. São Paulo: Perspectiva, 2010.

Menezes de Souza, Lyn Mário T. "Uma outra história, a escrita indígena no Brasil”. In: Ricardo, Beto; Ricardo, Fany. Povos indígenas no Brasil: 2001-2005. São Paulo: Instituto Socioambiental, 2006: 203- 208.

Pozzana, Claudia e Alessandro Russo. “Esta é uma outra China”. Tradução de Andréia Guerini. Poesia Sempre, [S.L], n²7, ano 14, 2007. 
Rothemberg, Jerome. Etnopoesia do milênio. Org. Sergio Cohn. Trad. Luci Collin. Rio de Janeiro: Azougue, 2006.

Risério, Antônio. Textos e Tribos. Rio de Janeiro: Imago, 1993.

Said, Edward W. Orientalismo. O Oriente como invenção do Ocidente. Tradução de Rosaura Eichenberg. São Paulo: Cia das Letras, 2007.

Sloterdjik, Peeter. Palácio de Cristal: para uma Teoria Filosófica da Globalização. Tradução de Manuel Resende, Lisboa: Relógio d'Água, 2008.

Schwarcz, Lilia M.; Starling, Heloísa M. Brasil: uma Biografia. $1^{\text {a }}$. Ed. São Paulo, Companhia das Letras, 2015.

Souza, Tania C. C. de. Línguas indígenas: memória, arquivo e oralidade. Policromias, [s.1], 1.2 (2017): 36-55. Disponível em: < https://revistas.ufrj.br/index.php/ policromias/article/view/7710/6228> . Acesso em: 16 de setembro de 2019.

Strathern, Marilyn. Partial Connections. Oxford, Altamira Press, 2014.

Viveiros de Castro, Eduardo. "A antropologia perspectivista e o método de equivocação controlada”. Tradução de Marcelo Giacomazzi Camargo e Rodrigo Amaro. Aceno - Revista de Antropologia do Centro-Oeste, 5 (10): 247-264. Disponível em: http://periodicoscientificos.ufmt.br/ojs/index.php/aceno/article/ view/8341. Acesso em: 19 de agosto de 2019.

Zhang, Jianbo. Tradução de obras de Jorge Amado: Um estudo de relações entre tradução e poder. Tese de doutoramento em Estudos Literários. Universidade de Macau, 2018.

Recebido em: 05/10/2019

Aceito em: 27/11/2019

Publicado em dezembro de 2019

Álvaro Faleiros. E-mail: alvarofaleiros@gmail.com

ORCID http://orcid.org/0000-0001-7507-7801 